\title{
Efficacy of Sclerotherapic Agents in the Treatment of Simple Ovarian Cysts Created by Experimental Rat Model
}

\section{Deneysel Rat Modeliyle Oluşturulan Basit Over Kistlerinin Tedavisinde Skleroterapik Ajanların Etkinliği}

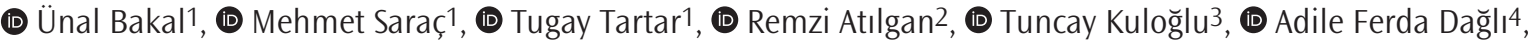 \\ (D) Ahmet Kazez ${ }^{1}$
}

${ }^{1}$ Firat University Faculty of Medicine Department of Pediatric Surgery, Elazığ, Turkey

2Fırat University Faculty of Medicine, Department of Obstetrics and Gynecology, Elazığ, Turkey

${ }^{3}$ Fırat University Faculty of Medicine, Department of Histology and Embryology, Elazı $\breve{g}$, Turkey

${ }^{4}$ Fırat University Faculty of Medicine, Department of Pathology, Elazı̆̆, Turkey

\begin{abstract}
Introduction: The purpose of this study is to investigate the effects of tetracycline (TC), clarithromycin (CM) and bleomycin (BLM) on the cyst diameter and ovarian tissues in the treatment of simple ovarian cysts.

Methods: We employed Wistar albino female rats $(n=38)$ to create ovarian cysts, and did not intervene in any form in the control group (GC) $(n=6)$. In total, 32 female rats underwent unilateral salpingectomy for the creation of cysts. Macroscopic cysts were manifested in 25 (78\%) rats who underwent salpingectomy. We divided the rats $(n=25)$ with cysts into four groups. Salpingectomy with saline was performed in G1, salpingectomy with tetracycline (TC) was performed in G2, and salpingectomy with Clarithromycin (CM) was performed in $\mathrm{G} 3$. Additionally, salpingectomy with BLM was exploited in G4.
\end{abstract}

Results: There was a significant decrease in the diameter of the cyst in G2 as compared to G1, but there was no significant difference among the other groups. There was no significant change in total ovarian reserve in the groups $(p=0.066)$. There was a statistically significant increase in fibrosis in G1 and $\mathrm{G} 3$ groups as compared to GC $(\mathrm{p}<0.0001)$. As compared to $\mathrm{G} 1$, fibrosis was significantly decreased in $\mathrm{G} 2(p=0.003)$ and $\mathrm{G} 4(\mathrm{p}=0.0001)$. TUNEL positivity was similar in $\mathrm{GC}$ and $\mathrm{G} 1$; however, there was a significant increase of TUNEL positivity in G2, G3 and G4 as compared to the control group ( $p<0.0001)$. In addition, there was a significant increase of adhesion in $\mathrm{G} 2$ $(p=0.030)$ and $\mathrm{G} 3(\mathrm{p}=0.010)$ as compared to $\mathrm{G} 1$.

Conclusion: TC is a more effective agent than CM and BLM in the sclerotherapy treatment of ovarian cysts. These three agents have no negative effect on the total ovarian reserves. There is an increasing need for further clinical studies regarding the

\section{öZ}

Amaç: Basit over kistlerinin tedavisinde Tetrasiklin, Klaritromisin ve Bleomisinin kist çapı ve over dokuları üzerine etkisini araștırmak.

Yöntemler: Over kistlerini oluşturmak için 38 Wistar albino rat ile çalışıldı. Kontrol grubuna $(G K)(n=6)$ hiçbir müdahale yapılmadı. Toplam 32 dişi Wistar albino cinsi ratta ise tek taraflı salpenjektomi yapıldı. İşlemden 1 ay sonra tüm ratlara laparotomi yapıldı. Salpenjektomi yapılanların 25 'inde (78\%) makroskobik kist oluşmuștu. Kist oluşan ratlar $(n=25) 4$ gruba ayrıldı. Grup 1'e (G1) salpenjektomi ve salin, Grup 2'ye (G2) salpenjektomi ve tetrasiklin (TC), Grup 3'e (G3) salpenjektomi ve klaritromisin (CM), Grup 4'e ise (G4) salpenjektomi ve bleomisin uygulandı.

Bulgular: G1 grubu ile karşılaștırıldığında G2 grubunda kist çapında anlamlı derecede azalma olduğu görüldü, diğer gruplar ile anlamlı farklılık yoktu. Kontrol grubu ile karşılaştırıldığında G1, G2, G3 ve G4 gruplarında toplam over rezervinde bir değişiklik izlenmedi $(p=0.066)$. Kontrol grubu ile karşılaştıııldığında G1 ve G3 gruplarında fibrozis istatistiksel olarak anlamlı artış gözlendi $(p<0.0001)$. G1 ile karşılaştırıldığında ise $G 2(p=0.003)$ ve G4 $(p=0.0001)$ gruplarında fibrozis istatistiksel olarak anlamlı şekilde azalmış gözlendi. TUNEL pozitifliği; GK ve G1 gruplarında benzerdi. Kontrol grubuyla kıyaslandığında ise G2, G3 ve G4 gruplarında anlamlı artış gözlendi $(p<0.0001)$. Adhezyon G1 grubuyla karşılaştırıldığında G2 $(p=0.030)$ ve $G 3(p=0.030)$ gruplarında anlamlı olarak artmıştı.

Sonuç: TC, over kistlerinin skleroterapisinde, klaritromisin ve bleomisinden daha etkili bir ajandır. Bu üç ajanın total over rezervleri üzerine olumsuz etkisi yoktur. Basit over kistlerinin 
use of sclerotherapy agents, primarily concerning the TC, in the treatment of simple ovarian cysts.

Keywords: Ovarian cyst, sclerotherapy, tetracycline, clarithromycin, bleomycin tedavisinde TC öncelikli olmak üzere skleroterapik ajanların kullanılabilmesi için klinik çalışmalara ihtiyaç vardır.

Anahtar Kelimeler: Over kisti, skleroterapi, tetrasiklin, klaritromisin, bleomisin

\section{Introduction}

Non-neoplastic ovarian cysts are the most commonly detected adnexal masses in menstruating females. Most of these cysts are functional and regress spontaneously (1). Follicular and luteal cysts are defined as the physiological ones, whereas pathologic cysts are classified as benign, malign or borderline ovarian tumours (2). Cysts that have diameters of up to $4 \mathrm{~cm}$ are mostly resolvable within 2-3 months. In case if the size of cyst increases or stays the same, then a cyst aspiration or operation is recommended (3). However, aspiration is generally not preferred because of tremendous recurrence rate of cysts, infectious complications and non-optimal histopathological data $(4,5)$. The classical treatment of a persistent ovarian cyst is exploratory laparotomy or laparoscopic resection (6). Minimally invasive therapies are some alternative methods that have been gaining popularity because of negligible surgical complications and the reduction of fertility rate in ovarian cysts during the treatment. It is reported that localized benign cysts observed in thyroid, parathyroid, liver, kidney or spleen regions can be treated effectively and cost-efficiently by applying ultrasound-guided aspiration and sclerosis (7). Sclerotherapy treatment can be considered for females who have ovarian cysts and do not want surgical treatments (8). Before sclerotherapy, it is crucial to consider the preoperative evaluation of the previous pathologic diagnosis, the midscalp serum CA 125 level and the coloured Doppler ultrasonography to exclude a possible chance of malignancy (9).

Tetracyclines, for example, doxycycline, tetracycline (TC) and minocycline, are regarded as the sclerosing agents that are applied in clinical settings such as pleural effusions, pneumothoraxes, hydroceles, benign lymphoepithelial cysts of the parotid gland and lymphoceles after renal transplantation (10). The results of local chemical irritation and inflammatory response are dedicated to the underlying setting of the sclerosing effect (10).

Clarithromycin (CM) is a powerful and effective semi-synthetic 14-membered macrolide. It is a prevalent antibiotic, combined with another antibiotic and an acid-suppressing agent, employed in the normal helicobacter pylori eradication regimens $(11,12)$.

Bleomycin (BLM) is a glycopeptide antibiotic, which is isolated from Streptomyces verticillus. It acts as an antineoplastic and antibiotic drug for the treatment of several cancers. The BLM breaks DNA in tumour cells, which induces apoptosis afterwards (13).

It is a potent and gentle sclerosant, which is widely used in the treatment of vascular malformations and cystic lesions such as mucoceles and renal cysts $(14,15)$.

The purpose of this study is to determine the effects of TC, CM and BLM on the cyst diameter and ovarian tissues as well as the sclerotherapy efficacy of TC, CM and BLM on simple ovarian cysts, which were created experimentally with salpingectomy in rats.

\section{Methods}

This study was conducted under the approval of the Firat University Institutional Animal Ethics Committee (Decree date: 14.05.2014, Decree no: 116). All experiments were conducted at Firat University Experimental Researches Laboratory FUTDAM, an institution authorized to perform non-clinical studies under the Good Laboratory Practice (GLP) regulations.

\section{Animals}

This study's design is based on the creation of experimental ovarian cyst generation model of Atilgan et al. (16). For the creation of ovarian cysts, we randomly picked 38 rats for performing salpingectomy. We selected 20 female Wistar albino rats aged 12-14 weeks old with weights ranging between 200 and 220 grams. We provided standard pellet feed and tap water to the rats within $12 \mathrm{~h}$ light/dark cycles at a room temperature $\left(21^{\circ} \mathrm{C}-23^{\circ} \mathrm{C}\right)$.

\section{Experimental Design}

We administered the rats with anaesthesia in form of ketamine and xylazine. The temperature in the operating room was kept at $20^{\circ} \mathrm{C}$. Afterward, we injected the dosages of $60 \mathrm{mg} / \mathrm{kg}$ of ketamine $\mathrm{HCL}$ (Ketalar, Eczacıbașı Warner-Lambert, İstanbul, Turkey) and $7 \mathrm{mg} / \mathrm{kg}$ of xylazine hydrochloride (Rompun, Bayer, İstanbul, Turkey) i.m. to the left hind foot of each rat. We placed the rats in the supine position on the operating table. The midline was accessed via incision.

\section{Surgical Technique}

We used Atilgan et al's (16) method to create ovarian cysts after performing right total salpingectomy. After achieving bleeding control, we sutured the abdomens of the rats with $3 / 0$ silk sutures. One month later, we re-explored the abdomens of the rats. We excluded the rats that did not develop cysts (seven rats) and had very small (diameter of less than $4 \mathrm{~mm}$ ) cysts from this study. We randomly separated 25 rats with macroscopic (diameter of more than $4 \mathrm{~mm}$ ) (Figure 1) ovarian cysts into four different groups with a prospective, single-blind design. The classification of the groups are as follows: TC is a more effective agent than CM and BLM

Group C (GC) ( $\mathrm{n}=6)$ : Control group, wherein the abdomens of rats were opened and closed.

Group 1 (G1) ( $n=6$ ): Saline was injected into the cyst and aspirated 5 minutes later as much as half of the aspirated fluid.

Group 2 (G2) ( $\mathrm{n}=6)$ : TC was injected into the cyst and aspirated 5 minutes later as much as half of the aspirated fluid.

Group $3(\mathrm{G} 3)(\mathrm{n}=6)$ : $\mathrm{CM}$ was injected into the cyst and aspirated 5 minutes later as much as half of the aspirated fluid. 
Group 4 (G4) ( $n=7$ ): BLM was injected into the cyst and aspirated 5 minutes later as much as half of the aspirated fluid.

\section{Histopathological Evaluation}

After cutting the right ovary, we put it into a solution with $10 \%$ formalin and sent to the laboratory. We prepared paraffin blocks for histopathological and histochemical examinations. Haematoxylin and eosin and Masson's trichrome stains were applied to the 5- $\mu$ m sections of paraffin blocks, which were investigated in this study. We examined the preparations and photographed them with a light microscope (Olympus BX-50).

According to the method of Souza et al. (17), we evaluated the reserve of ovarian follicles (primordial, primary, secondary and tertiary follicle counts) and fibrosis with light microscopy. We used Mazaud et al's (18) method for the microscopic identification of follicles. The follicles were identified as follows:

Primordial follicle: The oocytes were enclosed partly or totally by pregranulosa cells, which were flattened;

Primary follicle: The oocytes were expanded with the layer of one or more cuboidal cells amid the granulosa cells, which were flattened;

Secondary follicle: Two layers of granulosa cells or the second layer were present with one layer and one cell;

Preantral follicle: The oocytes were surrounded by two or more layers of granulosa cells without the formation of antrum;

Antral follicle: The oocytes were surrounded by two or more layers of granulosa cells in the formation of antrum;

The fibrosis was assessed by using Masson's trichrome stain. They were semi-quantitatively scored from 0 to $3(19,20)$. The scores are as follows:

$0=$ no fibrosis,

$+1=$ low fibrosis

$+2=$ intermediate fibrosis,

$+3=$ severe fibrosis

\section{The TUNEL Method}

The sections with the thicknesses of 5-6 $\mu \mathrm{m}$ were taken from the paraffin blocks and were put on polystyrene lamas. Apoptosis cells were detected by using the ApopTag Plus Peroxidase In Situ Apoptosis Detection Kit (Chemicon, catno: S7101, USA). The tissue sections that were deparaffinised with xylene were washed with phosphate buffered saline (PBS) by passing them through the graded alcohol series. The tissues that were incubated for 10 minutes with $0.05 \%$ proteinase $\mathrm{K}$ were additionally incubated for 4 minutes with 3\% hydrogen peroxide to prevent the endogenous peroxidase activity. After washing the tissue sections with PBS and incubating them with equilibration buffer for 6 minutes, they were further incubated for 60 minutes with the study's solution (70\% $\mu$ l Reaction Buffer and 30\% TdT Enzyme) in a humid environment at $37^{\circ} \mathrm{C}$. The tissues were kept in Stop/Wash Buffer for 10 minutes and treated with anti-digoxigenin-peroxidase for 30 minutes. Apoptotic cells were displayed with diaminobenzidine substrate.
Sections, which had contrasting dye with Harris haematoxylin, were closed by exploiting an appropriate closure solution. The preparations were evaluated and photographed by using the Novel N-800M microscope. For the evaluation of TUNEL dyeing, the blue-coloured nuclei with Harris haematoxylin were evaluated as normal, and the cells showing brown nuclear dyeing were considered as apoptotic. At least 500 normal and apoptotic cells were counted in the randomly selected areas of the sections with the magnification of 10 . Statistical analysis was performed by calculating the apoptosis index of the apoptosis cells and proportioning the number of apoptosis cells to the total number (normal + apoptosis) of cells.

\section{Statistical Analysis}

We employed the Statistical Package for the Social Sciences, version 21.0 (SPSS Inc., Chicago-USA) for analysing the data. Additionally, we compared the groups with the one-way ANOVA test and post hoc Tukey HSD test. For the comparisons, we considered $p<0.05$ as statistically significant value in our study.

\section{Results}

Table 1 shows the comparison of cyst diameters and adhesion strength among the groups.

\section{Histologic Results}

The examination of the ovarian tissue dyed with Masson's trichrome stains under the light microscope revealed that the ovarian tissue was normal in the control group (Figure 2). As compared to the control group (Figure 2A), there was no significant change of total ovarian reserve in the saline (Figure 2B), TC (Figure 2C), CM (Figure 2D) and BLM (Figure 2E) groups ( $p=0.066$ ). However, cyst formation was clearly observed in the G1, G2, G3 and G4 groups. In addition, fibrosis (black star) significantly increased in $G 1$ and $G 3$ groups as compared to $G C(p=0.001)$. As compared to the saline group, there was a statistically significant decrease in fibrosis in G2 $(p=0.0003)$ and G4 groups $(p=0.0001)$ (Table 2).

\section{TUNEL Results}

The examination of TUNEL dye for the detection of apoptotic cells under the light microscopy revealed TUNEL positivity in the secondary follicles of the ovarian tissue. TUNEL positivity (Figure 3) was similar in the control (Figure 3A) and saline (Figure 3B) groups. As compared to the control group, there was a significant increase in TUNEL positivity in TC (Figure 3C), CM (Figure 3D) and BLM (Figure 3E) groups $(\mathrm{p}<0.0001)$ (Table 3).

\section{Discussion}

Salpingectomy with TC, CM and BLM was applied for the creation of the ovarian cyst model. The comparison of the aspirated groups in ovarian cysts revealed a significant decrease for the cyst size in the TC group. There was no significant difference among the groups in the evaluation of ovarian reserve. There was a significant increase in the adhesion intensity in the group with saline than in the other groups. The adhesion intensity increased significantly in the TC, CM and BLM groups 
Table 1. Comparison of cyst diameters and adhesion strength between groups

\begin{tabular}{|c|c|c|c|c|}
\hline Groups & $\begin{array}{l}\text { Cyst Diameter } 1 \\
\text { (After salpingectomy) (mm) }\end{array}$ & $\begin{array}{l}\text { The amount of aspirated } \\
\text { fluid (cc) }\end{array}$ & $\begin{array}{l}\text { Cyst Diameter } 2 \\
\text { (After sclerotherapy) (mm) }\end{array}$ & $\begin{array}{l}\text { Severe score of } \\
\text { Adhesion }\end{array}$ \\
\hline GC & - & - & - & - \\
\hline G2 & $11.2 \pm 4.8$ & $0.4 \pm 0.2$ & $7.5 \pm 3.3^{d}$ & $0.7 \pm 0.3^{b}$ \\
\hline G3 & $12.2 \pm 5.2$ & $0.5 \pm 0.3$ & $9.2 \pm 5.6$ & $0.8 \pm 0.6^{c}$ \\
\hline \multicolumn{5}{|c|}{$\begin{array}{l}\text { a: There was a significant decrease between the saline and bleomycin groups in terms of the amounts of aspirated fluid }(p=0.022) \text {. For the comparison of the severe score of adhesio } \\
\text { there was a significant increase among the groups }(p=0.010) \text { : }\end{array}$} \\
\hline \multicolumn{5}{|c|}{ b: G1 and G2 (p=0.0301). } \\
\hline \multicolumn{5}{|c|}{ c: G1 and $\mathrm{G} 3(\mathrm{p}=0.107)$. } \\
\hline
\end{tabular}

\section{Table 2. Comparison of ovarian reserves among the groups (histoscore)}

\begin{tabular}{|c|c|c|c|c|c|c|}
\hline & Primordial & Primer & Secondary & Tertiary & Total & Fibrosis \\
\hline GC & $15.6 \pm 2.6$ & $12.4 \pm 1.1$ & $16.2 \pm 1.3$ & $3.4 \pm 1.3$ & $48 \pm 2.1$ & $0.5 \pm 0.8$ \\
\hline G1 & $15 \pm 3.2$ & $14.2 \pm 2.5$ & $16.8 \pm 3.7$ & $2.2 \pm 1.6$ & $47.8 \pm 4.7$ & $2.2 \pm 0.4^{\mathrm{a}}$ \\
\hline G2 & $15.7 \pm 2.9$ & $16.7 \pm 2.5$ & $19 \pm 3.5$ & $6 \pm 0.8$ & $54.5 \pm 6.7$ & $0.6 \pm 0.5^{b c d}$ \\
\hline G3 & $14.7 \pm 3.1$ & $15 \pm 3.6$ & $15.7 \pm 5.1$ & $4 \pm 1$ & $49.3 \pm 10$ & $2.3 \pm 0.5^{\mathrm{a}}$ \\
\hline G4 & $15.5 \pm 2.7$ & $15.5 \pm 2.1$ & $21.5 \pm 0.7$ & $2 \pm 1.4$ & $56.5 \pm 6$ & $0.5 \pm 0.5^{b}$ \\
\hline
\end{tabular}

The values are provided as mean \pm standard deviation. For the comparison of fibrosis, there was a significant increase between ( $p<0.001$ ):

a: Fibrosis was significantly increased in G1 and G3 as compared to GC ( $p=0.001)$.

b: Fibrosis was significantly decreased in $\mathrm{G} 2(\mathrm{p}=0.0003)$ and $\mathrm{G} 4(\mathrm{p}=0.001)$ as compared to $\mathrm{G} 1$.

: Fibrosis was significantly increased in $\mathrm{G} 2$ and $\mathrm{G} 3$ ( $p=0.0001)$.

d: Fibrosis was significantly increased in G3 and G4 ( $p<0.0001)$, GC: control group

\section{Table 3. Apoptotic index}

\begin{tabular}{|l|l|}
\hline & Apoptotic index (\%) \\
\hline GC & $2.6 \pm 0.5$ \\
\hline G1 & $2.8 \pm 1.3$ \\
\hline G2 & $11.3 \pm 0.9^{\mathrm{ab}}$ \\
\hline G3 & $11 \pm 4.2^{\mathrm{ab}}$ \\
\hline G4 & $14.8 \pm 3.1^{\mathrm{ab}}$ \\
\hline
\end{tabular}

The values are provided as mean \pm standard deviation. For the comparison of fibrosis, there was a significant increase between $(p<0.0001)$ :

a: Compared with GC $(p<0.0001)$.

b: Compared with G1 ( $p<0.0001), G C$ : control group
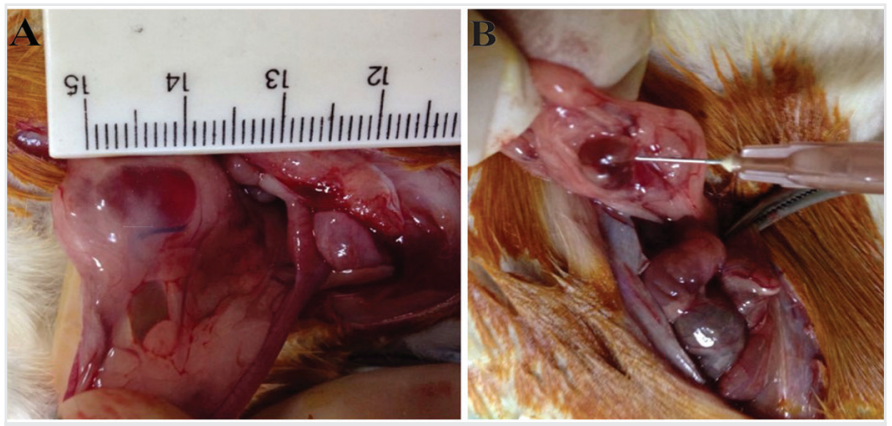

Figure 1. Image of macroscopic cysts in rats who underwent right total salpingectomy

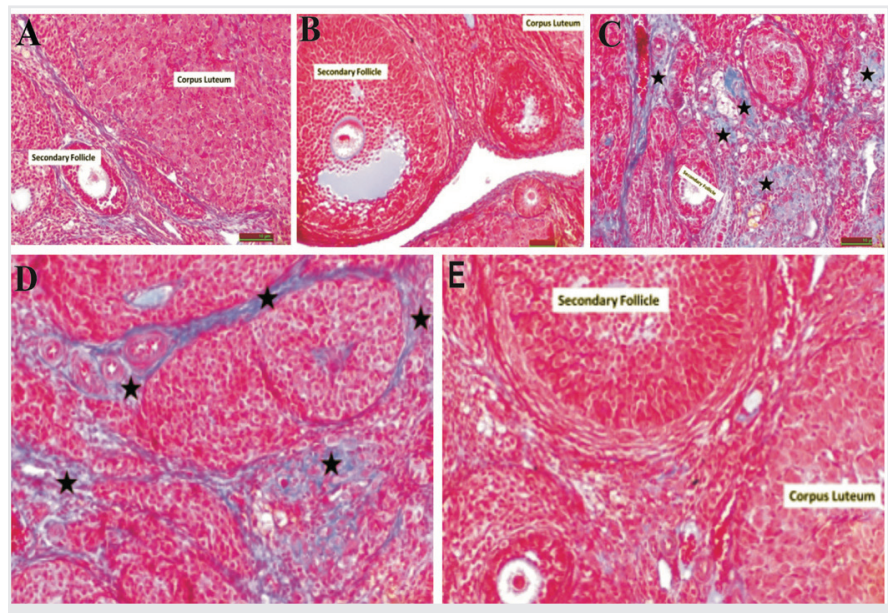

Figure 2. Examination of the ovarian tissue dyed with Masson's trichrome stain under the light microscope, the ovarian tissue was normal in the control group. As compared to the control group (Figure 2A), there was no significant change of ovarian reserve in the saline (Figure 2B), tetracycline (Figure 2C), clarithromycin (Figure 2D) and bleomycin (Figure 2E) groups

as compared to the control group. The apoptotic index in sclerotherapy groups was significantly increased as compared to both control and saline groups. Our experimental study showed that the sclerotherapy activity of TC was stronger than CM and BLM in the simple ovarian cysts. The sclerotherapy activity also decreased the cyst diameter. 


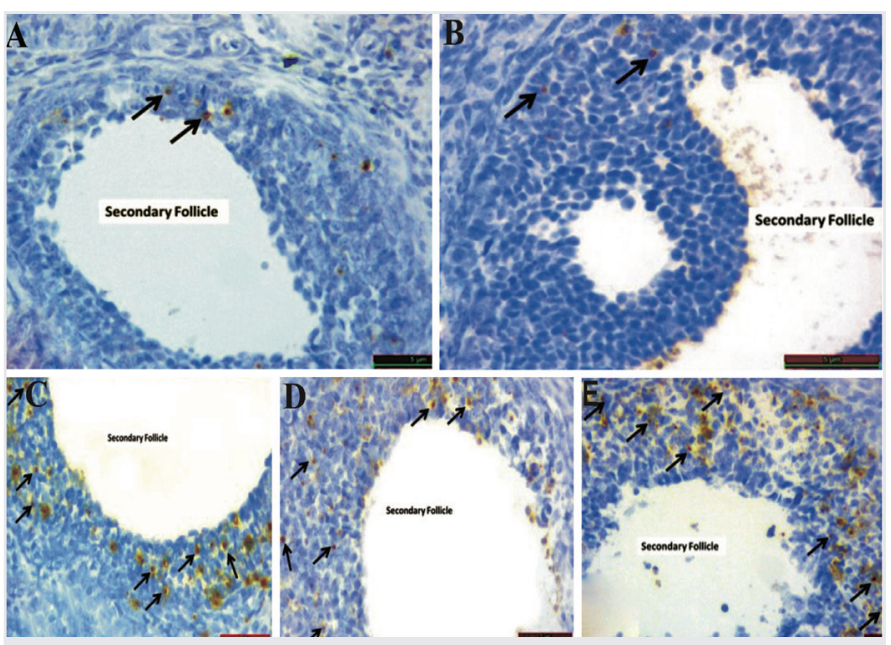

Figure 3. Light microscope images of TUNEL evaluation in groups (Figure 3A: Control group, Figure 3B: Group 1; saline, Figure 3C: Group 2; tetracycline, Figure 3D: Group 3; clarithromycin and Figure 3E: Group 4; bleomycin).

Although there is information about the use of TC and BLM in sclerotherapy treatment in various cysts, we have not found any considerable details regarding the use of $\mathrm{CM}$. Additionally, we have not determined any study in the literature that researched the use of these three sclerotherapy agents for treating ovarian cysts.

Sclerotherapy was normally utilised for the treatment of tuberculosis. Nowadays, oncologists can access the benefits of sclerotherapy for the treatment of cancer-induced pleural effusions. The sclerotherapy mechanisms in ovarian cysts have been not exactly determined in research works. However, it appears that the lining of epithelial cells is remarkable for the process of the disease. An adequate contact between the cyst wall and sclerosing agent activates a coagulation cascade and generates inflammatory mediators. In the case of this contact, the fibrosis of the lining of epithelial cells takes place and the adherence is leaded to the wall of the cyst (9). It is believed that the underlying mechanism of the sclerosing effect of TC is usually a result of local chemical irritation or an inflammatory response (10). In addition, $\mathrm{TC} \mathrm{HCl}$ causing low pH values can lead to sclerosis by producing cellular foreign body reaction. It is an antibiotic that causes cellular foreign body reaction that leads to sclerosis (10). Different results have been reported regarding the use of sclerotherapy with TC in various cysts. Kars et al (21) compared the aspiration of non-neoplastic ovarian cysts and sclerotherapy treatment with TC. There was no significant difference between these two groups in terms of the size of the cyst. However, recurrence rates were significantly lower in the TC group (14.6\% (7/48) vs. 50\% (24/48)). Ashindoitiang et al. (22) reported that the application of sclerotherapy with TC in the ganglion cysts significantly reduced the recurrence rate. Francis et al. (23) showed that aspiration and sclerotherapy with doxycycline had similar and successful results in the treatment of hydrocele cases. Fabrizzi et al. (24) performed sclerotherapy with TC to the symptomatic hepatic cysts of children and achieved successful results. This was suggested as an alternative method of laparoscopy. Kilinç et al. (25) showed that sclerotherapy with TC in the simple renal cysts significantly reduced the size of the cyst as compared to the aspiration group. The thorough analysis of abovementioned studies states that the antibiotics of TC group are very effective in preventing recurrences in various simple cysts. Our study observed a significant decrease for the size of the cyst only in the TC group as compared to the aspiration group. This may be due to the differences of tissue and species. In addition, the patients in the abovementioned studies had been usually followed between 3 months and 5 years. Our one-month control period might not be enough to examine the effect of sclerosis. Atilgan et al. (16) and Simsek et al. (26) showed that sclerotherapy with ethanol resulted in a significant decrease of the ovarian cysts after one month. Briefly, one month may be sufficient for alcohol and TC; however, this period may not be enough for the sclerosant effect in the cases of CM and BLM.

As an antitumor agent, the BLM obstructs DNA synthesis and may induce cell deaths (27). As a sclerosant, BLM causes endothelial cells to transdifferentiate myofibroblasts, which may encourage vascular fibrosis $(15,28)$. As compared to other sclerosants, the BLM has lower complication rates (27). Differently from ethanol, it does not lead to skin and mucosal necrosis $(27,29,30)$. The in vitro and vivo studies propose that endothelial cell death with apoptosis rather than necrosis may cause decreased inflammation and swelling, which is ascribed to BLM (15,28,31-33). Souftas et al. (34) applied sclerotherapy with BLM to the symptomatic simple abdominal cysts (liver, $n=14$; kidney, $n=3$; and adrenal, $n=2$ ). They noticed a significant decrease in the cyst volumes over time. Their study showed that 17 cysts completely disappeared in the $12^{\text {th }}$ month. There are case reports that sclerotherapy with BLM is successful in the treatment of the cases of lymphatic malformation (35) and parathyroid gland haemangioma. Azene et al. (36) demonstrated that the clinical results of foamed BLM were better than ethanol sclerotherapy in the treatment of airway venous malformations. We have not found any studies on the use of BLM for the sclerotherapy of ovarian cysts. From this aspect, our paper is the first study in the literature to report these findings. Our study did not find a significant decrease in the size of ovarian cyst as compared to the ovarian cyst size of BLM with aspiration and TC groups. We showed that BLM significantly decreased the ovarian fibrosis score as compared to the aspiration group. A period of one month might be insufficient to produce a sclerosant effect for BLM as well as for CM. We can state that BLM has no negative effect on the ovarian reserves. The difference of our study from the abovementioned sclerotherapy studies is the histopathological evaluation of ovarian tissue after sclerotherapy in all the groups in terms of fibrosis, apoptosis and ovarian reserve as well as the comparison of this treatment with the control group.

\section{Conclusion}

Although all three sclerotherapy agents do not affect the ovarian reserve, the sclerotherapy of simple ovarian cysts with TC is more effective than BLM and CM. In clinical applications, various studies with extensive range are needed for the use of these sclerotherapy agents in the sclerotic treatment of simple ovarian cysts.

Acknowledgments: The authors would like to thank Firat University for its funding (Project No. TF.14.49). 


\section{Ethics}

Ethics Committee Approval: This study was conducted under the approval of the Fırat University Institutional Animal Ethics Committee (Decree date: 14.05.2014, Decree no: 116).

\section{Informed Consent: N/O.}

Peer-review: Externally peer-reviewed.

Authorship Contributions: Surgical and Medical Practices - Ü.B., T.T., R.A.; Concept - Ü.B., M.S., T.K., A.F.D.; Design - Ü.B., M.S., R.A.; Data Collection or Processing - M.S., A.F.D., A.K.; Analysis or Interpretation T.T., A.F.D., A.K.; Literature Search - T.T., R.A., T.K., A.K.; Writing - Ü.B., T.T., T.K.

Conflict of Interest: No conflict of interest was declared by the authors.

Financial Disclosure: This study has been funded by the "Fırat University Scientific Research Project" (Project No. TF.14.49).

\section{References}

1. Kafali H, Yurtseven S, Atmaca F, Ozardali I. Management of non-neoplastic ovarian cysts with sclerotherapy. Int J Gynaecol Obstet 2003; 81: 41-5.

2. Liu H, Wang X, Lu D, Liu Z, Shi G. Ovarian masses in children and adolescents in China: analysis of 203 cases. J Ovarian Res 2013; 6: 47-52.

3. Mittal S, Kumar S, Kumar A, Verma A. Ultrasound guided aspiration of endometrioma--a new therapeutic modality to improve reproductive outcome. Int J Gynaecol Obstet 1999; 65: 17-23.

4. Marana R, Caruana P, Muzii L, Catalano GF, Mancuso S. Operative laparoscopy for ovarian cysts. Excision vs. aspiration. J Reprod Med 1996; 41: 435-8.

5. Zanetta G, Lissoni A, Torri V, Valle CD, Trio D, Rangoni G, Mangioni C. Role of puncture and aspiration in expectant management of simple ovarian cysts: a randomised study. BMJ 1996; 313: 1110-3.

6. Marana R, Ferrari S, Scarpa A, Muzii L. Laparoscopic treatment of adnexal cystic masses. Minerva Ginecol 2006; 58: 371-80.

7. Okagaki R, Osuga Y, Momoeda M, Tsutsumi O, Taketani Y. Laparoscopic findings after ultrasound-guided transvaginal ethanol sclerotherapy for ovarian endometrial cyst. Hum Reprod 1999; 14: 270-4.

8. Benagiano G, Guo S-W, Bianchi P, Puttemans P, Gordts S, Petraglia F, et al. Pharmacologic treatment of the ovarian endometrioma. Expert Opin Pharmacother 2016; 17: 2019-31.

9. Hsieh C-L, Shiau C-S, Lo L-M, Hsieh T-T, Chang M-Y. Effectiveness of ultrasoundguided aspiration and sclerotherapy with 95\% ethanol for treatment of recurrent ovarian endometriomas. Fertil Steril 2009; 91: 2709-13.

10. Liu F-S, Hung M-J, Hwang S-F, Lu C-H, Ke Y-M, Ho ES-C. Management of pelvic lymphocysts by ultrasound-guided aspiration and minocycline sclerotherapy. Gynecol Obstet Invest 2005; 59: 130-3.

11. Peterson WL, Graham DY, Marshall B, Blaser MJ, Genta RM, Klein PD, et al. Clarithromycin as monotherapy for eradication of Helicobacter pylori: a randomized, double blind trial. Am J Gastroenterol 1993; 88: 1860-4.

12. Mahalingan K, Rajarajan S, Baby B, Harsha NS. Formulation and evaluation of clarithromycin extended release tablets. J Pharm Sci Res 2009; 3: 97-100.

13. Mouratis MA, Aidinis V. Modeling pulmonary fibrosis with bleomycin. Curr Opin Pulm Med 2011; 17: 355-61.

14. Cai Y, Wang R, Yang S-F, Zhao Y-F, Zhao J-H. Sclerotherapy for the mucoceles of the anterior lingual salivary glands with pingyangmycin. Oral Dis 2014; 20: $473-6$.
15. Zhang W, Chen G, Ren J-G, Zhao Y-F. Bleomycin induces endothelial mesenchymal transition through activation of mTOR pathway: a possible mechanism contributing to the sclerotherapy of venous malformations. $\mathrm{Br}$ J Pharmacol 2013; 170: 1210-20.

16. Atilgan R, Ozkan ZS, Kuloglu T, Kocaman N, Baspinar M, Can B, et al. Impact of intracystic ethanol instillation on ovarian cyst diameter and adjacent ovarian tissue. Eur J Obstet Gynecol Reprod Biol 2013; 174: 133-6.

17. Souza AZ, Fonseca AM, Izzo VM, Clauzet RM, Salvatore CA. Ovarian histologyand function after total abdominal hysterectomy. Obstet Gynecol 1986; 68: 847-9.

18. Mazaud S, Guigon CJ, Lozach A, Coudouel N, Forest MG, Coffigny H, et al. Establishment of the reproductive function and transient fertility of female rats lacking primordial follicle stock after fetal gamma-irradiation. Endocrinology 2002; 143: 4775-87.

19. Sapmaz E, Kale A, Akpolat N. Melatonin use in unilateral total salpingectomy in rats. Clin Exp Obstet Gynecol 2012; 39: 186-90.

20. Samrao D, Wang D, Ough F, Lin YG, Liu S, Menesses T, et al. Histologic parameters predictive of disease outcome in women with advanced stage ovariancarcinoma treated with neoadjuvant chemotherapy. Transl Oncol 2012; 5: 469-74.

21. Kars B, Buyukbayrak EE, Karsidag AY, Pirimoglu M, Unal O, Turan C. Comparison of success rates of 'transvaginal aspiration and tetracycline sclerotherapy' versus 'only aspiration' in the management of non-neoplastic ovarian cysts. J Obstet Gynaecol Res 2012; 38: 65-9.

22. Ashindoitiang JA. Preliminary report of the effectiveness of tetracycline sclerotherapy in treatment of ganglion. Plast Surg Int 2012: 624209-624211.

23. Francis JJ, Levine LA. Aspiration and sclerotherapy: a nonsurgical treatment option for hydroceles. J Urol 2013; 189: 1725-9.

24. Fabrizzi G, Lanza C, Bolli V, Pieroni G. Symptomatic hepatic cyst in a child: treatment with single-shot injection of tetracycline hydrochloride. Pediatr Radiol 2009; 39: 1091-4.

25. Kilinc M, Tufan O, Guven S, Odev K, Gurbuz R. Percutaneous injection sclerotherapy with tetracycline hydrochloride in simple renal cysts. Int Urol Nephrol 2008; 40: 609-13.

26. Şimşek M, Kuloğlu T, Pala Ş, Boztosun A, Can B, Atilgan R. The effect of ethanol sclerotherapy of 5 minutes duration on cyst diameter and rat ovarian tissue in simple ovarian cysts. Drug Des Devel Ther 2015; 5; 9: 1341-7.

27. UI Haq F, Mitchell SE, Tekes A, Weiss CR. Bleomycin foam treatment of venous malformations: a promising agent for effective treatment with minimal swelling. J Vasc Interv Radiol 2015; 26: 1484-93.

28. Huang Y, Li P, Xia S, Zhuo Y, Wu L. Proapoptotic effect and the mechanism of action of pingyangmycin on cavernous hemangiomas. Exp Ther Med 2014; 7: 473-7.

29. Muir T, Kirsten M, Fourie P, Dippenaar N, Ionescu GO. Intralesional bleomycin injection (IBI) treatment for haemangiomas and congenital vascular malformations. Pediatr Surg Int 2004; 19: 766-73.

30. Zhi K, Wen Y, Li L, Ren W. The role of intralesional Pingyangmycin in the treatment of venous malformation of facial and maxillary region. Int J Pediatr Otorhinolaryngol 2008; 72: 593-7.

31. Mabeta P, Davis PF. The mechanism of bleomycin in inducing haemangioma regression. SAMJ 2008; 98: 538-40.

32. Li P, Li D-F, Guo Z-T, Xiao X. Therapeutic mechanism of bleomycin A5 on infancy hemangioma: an experimental study. Zhonghua Kou Qiang Yi Xue Za Zhi 2013; 48: 18-22. 
33. Li P, Xiao X, Guo Z-T. Effect of bleomycin A5 on the hemangioma-derived endothelial cell line XTPS-1. Zhonghua Kou Qiang Yi Xue Za Zhi 2012; 47: 324-8.

34. Souftas VD, Kosmidou M, Karanikas M, Souftas D, Menexes G, Prassopoulos P. Symptomatic abdominal simple cysts: is percutaneous sclerotherapy with hypertonic saline and bleomycin a treatment option? Gastroenterol Res Pract 2015: 489363
35. Vlahovic A, Gazikalovic A, Adjic 0. Bleomycin sclerotherapy for lymphatic malformation after unsuccessful surgical excision: case report. Acta Otorhinolaryngol Ital 2015; 35: 365-7.

36. Azene E, Mitchell S, Radvany M, Agrawal N, Eisele D, Weiss C. Foamed bleomycin sclerosis of airway venous malformations: The role of interspecialty collaboration. Laryngoscope 2016; 126: 2726-32. 